\title{
STEREOSPECIFIC SYNTHESIS AND ENZYME STUDIES OF CDP-DIACYLGLYCEROLS
}

\author{
PUSHPALATHA P.N. MURTHY and BERNARD W. AGRANOFF * \\ Neuroscience Laboratory Building, The University of Michigan, 1103 East Huron, Ann Arbor, MI 48109 (U.S.A.)
}

(Received March 15th, 1982)

Key words: Faty acid specificity; CDPdiacylglycerol synthesis; Phospholipid; Phosphatidyltransferase; Diacylglycerol synthesis

The fatty acid specificity of two enzymes that metabolize CDPdiacylglycerol, CDPdiacylglycerol hydrolase (EC 3.6.1.26) and CDPdiacylglycerol: inositol phosphatidyltransferase (EC 2.7.8.11), has been examined in guinea pig brain. Mixed CDPdiacylglycerols were stereospecifically synthesized by the following sequence: (i) hydrolysis of a homodiacyl lecithin to 1 -acyl lysoPC by action of snake venom phospholipase $A_{2}$, (ii) reacylation with the anhydride of the desired second fatty acid and dimethylaminopyridine, (iii) hydrolysis of the resultant heterodiacyl lecithin to phosphatidate with cabbage phospholipase $D$, and (iv) reaction of phosphatidate with CMPmorpholidate to give CDPdiacylglycerol. CDPdiacylglycerol: inositol phosphatidyltransferase showed the following rates of conversion of $40-\mu \mathrm{M}$ suspensions of CDPdiacylglycerol in $0.15 \%$ Triton X-100 to phosphatidylinositol relative to the 1-stearoyl-2-oleoyl derivative (100\%): dipalmitoyl, $70 \%$; distearoyl, 38\%; diarachidonoyl, 9\%; 1-arachidonoyl-2-stearoyl, 6\%; 1-stearoyl-2-arachidonoyl, 4\%. These results indicate that the composition of isolated phosphatidylinositol and related lipids is not explained by the fatty acid specificity of the biosynthetic enzymes and supports the intervention of a deacylation-reacylation sequence. The rates of hydrolysis of the synthetic CDPdiacylglycerols at $76 \mu \mathrm{M}$, in $0.3 \%$ Triton X-100, by the CDPdiacylglycerol hydrolase relative to the 1-stearoyl-2-oleoyl derivative $(100 \%)$ were: dipalmitoyl, 70\%; distearoyl, 32\%; 1-arachidonoyl-2-stearoyl, 30\%; 1-stearoyl-2-arachidonoyl, 28\%; diarachidonoyl, $22 \%$. Inhibition of this enzyme by AMP was shown to be non-competitive, with a $K_{i}$ of $40 \mu \mathrm{M}$. The lysosomal localization of the mammalian hydrolase was confirmed.

\section{Introduction}

The liponucleotide, CDPdiacylglycerol is an obligatory intermediate in the biosynthesis of the phosphatidylinositols and the phosphatidylglycerols. Phosphoinositides, including phosphatidylinositol (PI), phosphatidylinositol phosphate and phosphatidylinositol bisphosphate isolated from tissue sources are highly enriched in the 1-stearoyl-2-arachidonoyl species, which can

\footnotetext{
* To whom correspondence should be addressed. Abbreviations: PA, phosphatidate; PI, phosphatidylinositol; PC, phosphatidylcholine, or lecithin; CDPdiacylglycerol, cytidine-5'-diphospho-1,2-diacyl-sn-glycerol.
}

account for $70-80 \%$ of the isolated phospholipid [1-5]. The 1-stearoyl-2-arachidonoyl enrichment may be related to the observation in a number of tissues, that increased metabolic turnover of PI and of phosphatidate (PA) results from physiological stimulation [6]. In vitro stimulation of blood platelets by the addition of thrombin leads to stimulated labeling from ${ }^{32} \mathrm{P}_{\mathrm{i}}$ of PA and PI as well as increased release of arachidonate [7], and it has been suggested that the stimulated phospholipid labeling is the reflection of PI breakdown and resynthesis as part of a process by which arachidonate is released [8]. The original composition of the platelets is ultimately restored, although how stearate and arachidonate enrichment 
reappears in PI is not clear. Stimulated labeling of PA and PI in synaptosomes by muscarinic agents is well-documented, although a possible relationship with arachidonate release is not presently known [9]. The present studies were initiated to relate better the observed stimulated labeling in synaptosomes to the fatty acid specificities for substrates by enzymes that mediate the interconversion of the relevant lipids.

\section{Materials and Methods}

The following materials were purchased from Sigma Chemical Company, St. Louis, MO: arachidonic acid, stearic acid, oleic acid, L- $\alpha$-dipalmitoylPC, L- $\alpha$-distearoylPC, $s n$-glycero-3-phosphorylcholine, bovine serum albumin, cabbage phospholipase D (40 units $/ \mathrm{mg}$ ), and Triton X-100. Dicyclohexylcarbodiimide and 4-dimethylaminopyridine were obtained from Aldrich Chemical Company, Inc., Milwaukee, WI. $\left[5-{ }^{3} \mathrm{H}\right]$ Cytidine5'-monophosphate $(15-30 \mathrm{Ci} / \mathrm{mmol})$ was obtained from Amersham-Searle, Chicago, IL and [5${ }^{3} \mathrm{H}$ ]cytidine-5'-triphosphate $(24.6 \mathrm{Ci} / \mathrm{mmol})$ was purchased from New England Nuclear, Boston, MA. Snake venom phosphodiesterase was purchased from Boehringer-Mannheim, Indianapolis, IN. Rattlesnakc (Crotalus adamantus) venom, used as a source of phospholipase $\mathrm{A}_{2}$, was purchased from Miami Serpentarium Laboratories, Miami, FL. A mixed bed, ion-exchange resin (Rexyn-I-300) and DEAE-cellulose (DE 52 microgranular) were obtained from Fisher Scientific, Fair Lawn, NJ and Whatman, Inc., Clifton, NJ, respectively. Dowex 50W-X8 (200-400 mesh, $\mathrm{H}^{+}$form) was purchased from Bio-Rad Laboratories, Richmond, CA.

Chloroform and carbon tetrachloride were dried by distilling from phosphorus pentoxide diethyl ether by distilling from lithium aluminum hydride, and benzene by distilling from sodium wire. All solvent mixtures are expressed on a volume basis.

NMR spectra were recorded in a Bruker 360 $\mathrm{MHz}$ spectrophotometer. Gas chromatographic analysis of the fatty acid methyl esters was performed in a Hewlett-Packard 5710A gas chromatograph interfaced with a computing integrator. The column was made of $15 \%$ diethylene- glycol succinate on Chromosorb W (AW) 60/80 mesh (Applied Science, State College, PA). A temperature program varying from 160 to $210^{\circ} \mathrm{C}$ was used.

Pre-coated silica gel 60 (250 $\mu \mathrm{m}$ thickness) and HPTLC silica gel 60 plates (E. Merck) were used for TLC. The solvent systems used were: (A) chloroform/methanol/water $(65: 25: 4)$ and (B) chloroform/methanol/acetic acid/water $(50: 32: 11: 3)$. Lipids were visualized by the phosphate spray described by Dittmer and Lester [10], exposure to iodine, or by charring with copper/ phosphoric acid spray [11].

Protein was determined spectrophotometrically [12] using bovine serum albumin as a standard. Total lipid phosphorus was determined by the method of Ames and Dubin [13].

\section{Enzyme studies}

CDPdiacylglycerol:inositol phosphatidyltransferase was prepared from guinea pig brain [14] and assayed by measuring the inositol-dependent release of radioactive CMP from CDPdiacylglycerol. The reaction mixture contained approximately 30 $\mu \mathrm{g}$ of protein in $175 \mathrm{mM}$ Tris- $\mathrm{HCl}$ buffer ( $\mathrm{pH} \mathrm{8.3)}$, $1.4 \mathrm{mM}$ inositol, $52.5 \mathrm{mM} \mathrm{MgCl}{ }_{2}$, and the indicated concentrations of Triton and CDPdiacylglycerol in a total volume of $0.2 \mathrm{ml}$. Incubations were conducted at $37^{\circ} \mathrm{C}$ for $8 \mathrm{~min}$. No CMP was released in the absence of added inositol. Glycerophosphate did not substitute.

CDPdiacylglycerol hydrolase was purified from guinea pig brain and assayed by measuring the release of radioactive CMP from labeled CDPdiacylglycerol [15]. The reaction mixture contained approximately $4 \mu \mathrm{g}$ of protein in $0.1 \mathrm{M}$ Trismaleate buffer ( $\mathrm{pH} 4.8$ ) and various concentrations of Triton and CDPdiacylglycerol in a total volume of $0.1 \mathrm{ml}$. Incubations were conducted at $37^{\circ} \mathrm{C}$ for $30 \mathrm{~min}$.

Peroxisomes were separated from lysosomes by a Metrizamide density gradient [16]. Catalase was measured by the method of Peters et al. [17] and acid phosphatase was determined by the procedure of Baudhuin [18].

\section{Chemical syntheses \\ The synthesis of 1-stearoyl-2-arachidonoyl CDPdiacylglycerol is described below. Other}


CDPdiacylglycerols used in this study were synthesized by the same procedure (Fig. 1), obtained in comparable yields and judged homogeneous by TLC.

Fatty acid anhydrides [19]. A solution of dicyclohexylcarbodiimide (150 $\mathrm{mg} ; 0.73 \mathrm{mmol}$ ) in dry $\mathrm{CCl}_{4}(3 \mathrm{ml})$ was added to a solution of arachidonic acid (400 $\mathrm{mg} ; 1.31 \mathrm{mmol}$ ) in dry $\mathrm{CCl}_{4}$ $(9 \mathrm{ml})$ and stirred at room temperature under an $\mathrm{N}_{2}$ atmosphere for $8 \mathrm{~h}$. The residue obtained by rotary evaporation was extracted with dry diethyl ether, filtered to remove the solid (dicyclohexylurea) and the filtrate concentrated to yield the oily fatty acid anhydride ( $354 \mathrm{mg} ; 0.6 \mathrm{mmol}$ ) in $92 \%$ yield. Infrared $\left(\nu_{\max }, \mathrm{CHCl}_{3}, \mathrm{~cm}^{-1}\right): 1830$

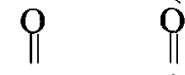

and $1750(\mathrm{C}-\mathrm{O}-\mathrm{C})$. NMR $\left(\mathrm{C}^{2} \mathrm{HCl}_{3} /\right.$ trimethylsilane $\delta): 5.35(\mathrm{~m}, \mathrm{CH}=\mathrm{CH}, 8 \mathrm{H}), 2.8$ (broad multiplet, $\left.\mathrm{C}=\mathrm{C}-\mathrm{CH}_{2}-\mathrm{C}=\mathrm{C}, 6 \mathrm{H}\right), 2.3\left(\mathrm{t}, \mathrm{CH}_{2}-\mathrm{C}=0\right.$, $J=7.6 \mathrm{~Hz}, 2 \mathrm{H}), 2.1\left(\mathrm{q}, \mathrm{C}=\mathrm{C}-\mathrm{CH}_{2}, \bar{J}=7.3 \mathrm{~Hz}\right.$, $2 \mathrm{H}), 2.0\left(\mathrm{q}, \mathrm{C}=\mathrm{C}-\mathrm{CH}_{2}, J=6.9 \mathrm{~Hz}, 2 \mathrm{H}\right), 1.7$ (quintet, $\mathrm{CH}_{2}-\mathrm{CH}_{2}-\overline{\mathrm{C}}=0, J=7.4 \mathrm{~Hz}, 2 \mathrm{H}$ ), 1.2 1.4 (broad multiplet, $\left.-\mathrm{CH}_{2}-, 6 \mathrm{H}\right), 0.9\left(\mathrm{t},-\mathrm{CH}_{3}\right.$, $J=7 \mathrm{~Hz}, 3 \mathrm{H}$ ).

Hetero-1,2-diacyl-sn-glycero-3-phosphorylcholine via lysophosphatidylcholine [20]. To a solution of distearoylPC (200 $\mathrm{mg} ; 0.25 \mathrm{mmol})$ in a mixture of diethyl ether $(40 \mathrm{ml})$ and methanol $(2.4 \mathrm{ml})$ was added a solution of 1-2 mg of rattlesnake venom in $10 \mathrm{ml}$ of borate buffer $(0.1 \mathrm{M}, \mathrm{pH} 7.4)$ containing $\mathrm{CaCl}_{2}(0.72 \mathrm{mM})$. The reaction mixture was vigorously stirred and heated under reflux at $37^{\circ} \mathrm{C}$ for $3 \mathrm{~h}$. Progress of the reaction was followed by TLC solvent system A. After completion of the reaction the organic layer (containing the falty acid) and the aqueous layer (containing the lyso compound) were separated. The aqueous layer was washed with diethyl ether and lyophilized. The residue was extracted with $\mathrm{CHCl}_{3} / \mathrm{CH}_{3} \mathrm{OH}(2: 1)$ and centrifuged. The clear supernatant was concentrated and washed with dry diethyl ether until the calcium salt of lysoPC was obtained as an amorphous solid (126 mg; $R_{\mathrm{F}}$ in solvent system A, HPTLC silica gel $60,0.2$ ). It was dried by repeated evaporation from dry benzene and lyophilization from cyclohexane and converted to the 1,2-diacylPC as follows [21]: dimethyl-4-aminopyridine, recrystallized from chloroform/diethyl ether (53 $\mathrm{mg} ; 0.43 \mathrm{mmol}$ ), fatty acid anhydride $(255 \mathrm{mg}$; $0.43 \mathrm{mmol}$ ) and lysoPC (126 $\mathrm{mg} ; 0.22 \mathrm{mmol}$ ) were suspended in $6 \mathrm{ml}$ of freshly distilled dry $\mathrm{CHCl}_{3}$ and the reaction mixture stirred at room temperature for $24-36 \mathrm{~h}$. The reaction was followed as above ( $R_{\mathrm{F}}$ of PC, HPTLC silica gel $60,0.73$ ). The solvent was removed under reduced pressure and the residue suspended in $5 \mathrm{ml}$ of $\mathrm{CH}_{3} \mathrm{OH} /$ $\mathrm{CHCl}_{3} / \mathrm{H}_{2} \mathrm{O}(5: 4: 1)$. The insoluble residue was removed and the clear solution passed through an $8 \mathrm{ml}$ column of Rexyn-I-300 resin. The resin was washed with an additional $20 \mathrm{ml}$ of the same solvent, and the combined eluate was concentrated and purified by silica gel chromatography (145 $\mathrm{mg} ; 0.18 \mathrm{mmol} ; 72 \%$ from distearoylPC). PC was eluted with $\mathrm{CHCl}_{3} / \mathrm{CH}_{3} \mathrm{OH}(65: 35)$. The product was obtained as an oil following solvent evapora-

tion. Infrared $\left(\nu_{\text {max }}, \mathrm{CHCl}_{3}, \mathrm{~cm}^{-1}\right): 1740(-\mathrm{C}-$ O), $1650(\mathrm{C}=\mathrm{C})$. NMR $\left(\mathrm{C}^{2} \mathrm{HCl}_{3} /\right.$ trimethylsilane, $\delta): 5.53(\mathrm{~m}, \mathrm{CH}=\mathrm{CH}, 8 \mathrm{H}), 5.17(\mathrm{~m}, \mathrm{CH}-\mathrm{O}, 1 \mathrm{H})$, 4.39 (dd, $\left.\mathrm{CH}_{2}-\mathrm{O}-\mathrm{P}, J=3 \mathrm{~Hz}, 12 \mathrm{~Hz}, 1 \mathrm{H}\right), 4.33$ (broad multiplet, $\mathrm{P}-\mathrm{O}-\mathrm{CH}_{2}-\mathrm{CH}_{2}-\mathrm{N}, 2 \mathrm{H}$ ), 4.1 (dd, $\mathrm{CH}_{2}-\mathrm{O}-\mathrm{P}, J=7 \overrightarrow{\mathrm{Hz}}, 12 \mathrm{~Hz}, 1 \mathrm{H}$ ), 3.96 (broad dd, $\mathrm{CH}_{2}-\mathrm{O}-\mathrm{C}, J=12 \mathrm{~Hz}, 5 \mathrm{~Hz}, 2 \mathrm{H}$ ), 3.8 (broad multiplet, $\mathrm{CH}_{2}-\mathrm{N}, 2 \mathrm{H}$ ), 3.3 (s, N$\left(\mathrm{CH}_{3}\right)_{3}, 9 \mathrm{H}$ ), 2.8 (broad multiplet, $\mathrm{C}=\mathrm{C}-\mathrm{CH}_{2}-$ $\mathrm{C}=\mathrm{C}, 6 \mathrm{H}$ ). 2.2-2.3 (two overlapping triplets centered at 2.24 and $2.29,-\mathrm{CH}_{2}-\mathrm{C}=0$ of stearoyl and arachidonoyl groups, $J=7.7 \mathrm{~Hz}, 4 \mathrm{H}$ ), 2.05 (multiplet, two overlapping quartets, $\mathrm{C}=\mathrm{C}-$ $\mathrm{CH}_{2}, 4 \mathrm{H}$ ), 1.65 (quintet, $\mathrm{CH}_{2}-\mathrm{CH}_{2}-\mathrm{C}=0$, arachidonoyl, $J=7.5 \mathrm{~Hz}, 2 \mathrm{H}$ ), 1.54 (broad multiplet, $\mathrm{CH}_{2}-\mathrm{CH}_{2}-\mathrm{C}=0$ stearoyl, $\left.2 \mathrm{H}\right), 1.2(\mathrm{~m}$, $-\mathrm{CH}_{2}=, 32 \mathrm{H}$ ), 0.85 (two overlapping triplets, $\left.-\mathrm{CH}_{3}, 6 \mathrm{H}\right)$.

Hetero-1,2-diacyl-sn-glycero-3-phosphoric acid [22]. To the suspension of 1-stearoyl-2-arachidonoylPC (125 mg; $0.15 \mathrm{mmol})$ in $13 \mathrm{ml}$ of $0.2 \mathrm{M}$ sodium acetate buffer ( $\mathrm{pH} \mathrm{5.6)}$ and $2.7 \mathrm{ml}$ of $1 \mathrm{M}$ $\mathrm{CaCl}_{2}$ were added $4 \mathrm{mg}$ of phospholipase $\mathrm{D}$ and 7 $\mathrm{ml}$ of diethyl ether. The mixture was stirred overnight at room temperature. The reaction was followed by TLC ( $R_{\mathrm{F}}$ of PA in solvent system $\mathrm{B}$, HPTLC silica gel $60,0.94)$. The reaction mixture was transferred to a separatory funnel and mixed with $50 \mathrm{ml}$ of methanol, followed by $50 \mathrm{ml}$ of $\mathrm{CHCl}_{3}$. The aqueous layer was acidified to $\mathrm{pH} 1$ 
(pH paper) with $6 \mathrm{M} \mathrm{HCl}$. The organic layer was concentrated and the crude product purified by silica gel chromatography to yield 1-stearoyl-2arachidonoyl PA as an amorphous solid $(93 \mathrm{mg}$; $0.13 \mathrm{mmol} ; 87 \%)$. Infrared ( $\left.\nu_{\max }, \mathrm{CHCl}_{3}, \mathrm{~cm}^{-1}\right)$ :

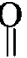

1740 ( $-\mathrm{C}-\mathrm{O}-$ ). NMR resonances were very broad and unresolved in all solvents examined $\left(\mathrm{C}^{2} \mathrm{HCl}_{3}\right.$ /trimethylsilane, $\left.\delta\right): 5.5(\mathrm{CH}=\mathrm{CH}, 9 \mathrm{H})$, 4.4-3.8 $\left(\mathrm{CH}_{2}-\mathrm{O}, \mathrm{CHO}, 5 \mathrm{H}\right), 2.8\left(\mathrm{C}=\mathrm{C}-\mathrm{CH}_{2}-\right.$ $\mathrm{C}=\mathrm{C}, 6 \mathrm{H}), 2.3-2.2\left(-\mathrm{CH}_{2}-\mathrm{C}=\mathrm{O}, 4 \mathrm{H}\right), 2.1-2.0$ $\left(\mathrm{C}=\mathrm{C}-\mathrm{CH}_{2}, 4 \mathrm{H}\right), 1.7-1.4\left(\mathrm{CH}_{2}-\mathrm{CH}_{2}-\mathrm{C}=\mathrm{O}\right.$, $4 \mathrm{H}), 1.2\left(-\mathrm{CH}_{2}-, 32 \mathrm{H}\right), 0.85\left(-\mathrm{CH}_{3}, 6 \mathrm{H}\right)$.

$\left[5-{ }^{3} \mathrm{H}\right] \mathrm{Cytidine}-5^{\prime}$-monophosphate from [5${ }^{3} \mathrm{H}$ ]cytidine- $5^{\prime}$-triphosphate. In initial studies [5$\left.{ }^{3} \mathrm{H}\right] \mathrm{CMP}$ was obtained commercially. In subsequent experiments, it was made by the enzymatic hydrolysis of $\left[5-{ }^{3} \mathrm{H}\right] \mathrm{CTP}[23]$. To $\left[5-{ }^{3} \mathrm{H}\right]$ cytidine5 -triphosphate $(500 \mu \mathrm{Ci} ; 24.6 \mathrm{Ci} / \mathrm{mmol})$ in $10 \mu \mathrm{l}$ of water was added $70 \mu 1$ of $1.0 \mathrm{M}$ Tris- $\mathrm{HCl}$ buffer (pH 8.9) and $20 \mu 1$ of phosphodiesterase solution ( 1.5 units $/ \mathrm{mg}$ per $\mathrm{ml}$ ). The reaction mixture was incubated at $37^{\circ} \mathrm{C}$ for $60 \mathrm{~min}$ and then applied to Whatman No. 1 filter paper and subjected to high-voltage electrophoresis $(4000 \mathrm{~V}, 45 \mathrm{~min})$ in pyridine/acetate buffer (pII 4.3). The tritiumlabeled compounds were located by autoradiography on Kodak XRP-5 X-ray film. No CTP was detected. CMP was recovered (70\%) from the paper by repeated extraction with $0.01 \mathrm{M} \mathrm{HCl}$. The aqueous solution was concentrated and combined with $300 \mathrm{mg}$ of unlabeled CMP sodium salt before passing through a $10 \mathrm{ml}$ Dowex- $\mathrm{H}^{+}$column. The CMP-free acid was eluted with $0.01 \mathrm{M} \mathrm{HCl}$, the aqueous solution concentrated to $5 \mathrm{ml}$ and converted to $\left[5-{ }^{3} \mathrm{H}\right]$ cytidine- $5^{\prime}$-monophosphomorpholidate [24]. The resultant product had a specific activity of $0.48 \mathrm{mCi} / \mathrm{mmol}$. Ultraviolet: $\lambda_{\max }=$ $278 \mathrm{~nm}$. NMR $\left({ }^{2} \mathrm{H}_{2} \mathrm{O}, \delta\right): 7.8$ (d, cytidine- $6, J=$ $7.5 \mathrm{~Hz}, 1 \mathrm{H}$ ), 5.9 (d, cytidine- $5, J=7.5 \mathrm{~Hz}, 1 \mathrm{H}$ ), 5.8 (d, ribose-1, $J=4.0 \mathrm{~Hz}, 1 \mathrm{H}$ ), 4.2-3.8 (ribose$\left.2^{\prime}, 3^{\prime}, 4^{\prime}, 5^{\prime}, 5 \mathrm{H}\right), 3.8-2.9\left(\mathrm{CH}_{2} \mathrm{O}, \mathrm{CH}_{2} \mathrm{~N}, \mathrm{CHO}\right.$, CHN, $18 \mathrm{H})$ 2.09-1.0 (m, cyclohexyl $-\mathrm{CH}_{2}-$, 20H).

$\left[5-{ }^{3} \mathrm{H}\right] \mathrm{Cytidine}-5^{\prime}$-diphospho-1-stearoyl-2-arachidonoyl-sn-glycerol [24,25]. A mixture of 1stearoyl-2-arachidonoylPA ( $30 \mathrm{mg} ; 0.04 \mathrm{mmol}$ ) and the 4-morpholine- $N, N^{\prime}$-dicyclohexylcarboxamide salt of $\left[5-{ }^{3} \mathrm{H}\right]$ cytidine- $5^{\prime}$-monophosphomorpholidate (40 $\mathrm{mg} ; 0.058 \mathrm{mmol} ; 0.48 \mathrm{mCi} / \mathrm{mmol}$ ) was dried by repeated lyophilization from dry benzene $(4 \times 5 \mathrm{ml})$. The residue was suspended in $2 \mathrm{ml}$ of freshly distilled dry pyridine under dry nitrogen atmosphere and stored in an evacuated desiccator over $\mathrm{P}_{2} \mathrm{O}_{5}$. The reaction was followed by TLC (solvent system B). After 5 days the reaction mixture was evaporated to dryness and the residue dissolved in $2 \mathrm{ml}$ of $\mathrm{CHCl}_{3} / \mathrm{CH}_{3} \mathrm{OH} / \mathrm{H}_{2} \mathrm{O}$ $(2: 3: 1)$. The solution was cooled to $0^{\circ} \mathrm{C}$ and the $\mathrm{pH}$ of the solution adjusted to 3.5 with cold $0.01 \mathrm{M}$ $\mathrm{HCl}$. The chloroform and aqueous layers were separated and the aqueous layer re-extracted with chloroform $(2 \times 5 \mathrm{ml})$. The combined chloroform layers were washed with water and concentrated. The residue was dissolved in $4 \mathrm{ml}$ of $\mathrm{CHCl}_{3} / \mathrm{CH}_{3} \mathrm{OH} / \mathrm{H}_{2} \mathrm{O}(2: 3: 1)$ and loaded on a cooled $\left(4^{\circ} \mathrm{C}\right)$ DEAE-cellulose (acetate) column $(1.5 \times 20 \mathrm{~cm})$. The column was washed with $80 \mathrm{ml}$ of $\mathrm{CHCl}_{3} / \mathrm{CH}_{3} \mathrm{OH} / \mathrm{H}_{2} \mathrm{O}(2: 3: 1)$ and a $1-1$ linear ammonium acetate gradient $(0-0.15 \mathrm{M}$ in $\left.\mathrm{CHCl}_{3} / \mathrm{CH}_{3} \mathrm{OH} / \mathrm{H}_{2} \mathrm{O}, 2: 3: 1\right)$ was commenced at $4^{\circ} \mathrm{C}$. Fractions containing CDPdiacylglycerol were collected, concentrated and lyophilized. The residue was partitioned between $\mathrm{CHCl}_{3} / \mathrm{H}_{2} \mathrm{O}(4: 1)$ and the chloroform layer concentrated to yield the oily diammonium salt of CDPdiacylglycerol (34 $\mathrm{mg} ; 0.032 \mathrm{mmol} ; 80 \%$ ). The $R_{\mathrm{F}}$ in solvent system $\mathrm{B}$, silica gel 60 , was 0.48 . The ammonium salt was suspended in water by sonication and used in enzyme assays.

For analytical studies an aliquot of the diammonium salt was converted to the disodium salt by passage through a Dowex-50- $\mathrm{Na}^{+}$column in $\mathrm{CHCl}_{3} / \mathrm{CH}_{3} \mathrm{OH} / \mathrm{H}_{2} \mathrm{O}(2: 3: 1)$. Molar absorptivities of the disodium salt in $\mathrm{CHCl}_{3} / \mathrm{CH}_{3} \mathrm{OH} / \mathrm{H}_{2} \mathrm{O}$ (2:3:1) were: $\lambda_{\max } 278 \mathrm{~nm}, 7200 ; \lambda_{\min } 248 \mathrm{~nm}$, 3600. Infrared $\left(\nu_{\max }, \mathrm{CHCl}_{3}, \mathrm{~cm}^{-1}\right): 1740(\mathrm{C}-\mathrm{O}$, $\mathrm{C}=\mathrm{O}$ ) NMR spectra in a number of solvents were examined. Only in $\mathrm{C}^{2} \mathrm{HCl}_{3} / \mathrm{C}^{2} \mathrm{H}_{3} \mathrm{O}^{2} \mathrm{H} /{ }^{2} \mathrm{H}_{2} \mathrm{O}$ $(2: 3: 1)$ were the NMR peaks of disodium or diammonium CDPdiacylglycerol well-resolved. $\delta 8.28$ (d, cytidine- $6, J=7.6 \mathrm{~Hz}, 1 \mathrm{H}$ ), 6.15 (bs, cytidine-5, $J=7.6 \mathrm{~Hz}, 1 \mathrm{H}), 5.9\left(\mathrm{~d},\left(\mathrm{l}^{\prime}\right.\right.$-ribose, $J=$ $3.4 \mathrm{~Hz}, 1 \mathrm{H}), 5.35(\mathrm{~m}, \mathrm{CH}=\mathrm{CH}$, arachidonic acid, $8 \mathrm{H}), 5.25$ (bs, $-\mathrm{CH}-\mathrm{O}$ glycerol, $1 \mathrm{H}), 4.9-4.0$ 
(multiplet, $\mathrm{HO}^{2} \mathrm{H}, \mathrm{C}^{2} \mathrm{H}_{3} \mathrm{OH}$, carbinol hydrogens, see NMR of $\mathrm{PC}$ ), 2.8 (broad multiplet, $\mathrm{C}=\mathrm{C}-$ $\left.\mathrm{CH}_{2}-\mathrm{C}=\mathrm{C}, 6 \mathrm{H}\right), 2.2-2.3\left(-\mathrm{CH}_{2}-\mathrm{C}=\mathrm{O}-\right.$ of stearoyl and arachidonoyl groups, $4 \mathrm{H}), 2.0-2.15$ (multiplet $\left.\mathrm{C}=\mathrm{C}-\mathrm{CH}_{2}, 4 \mathrm{H}\right), 1.65\left(\mathrm{~m}, \mathrm{CH}_{2}-\mathrm{CH}_{2}\right.$ $-\mathrm{C}=\mathrm{O}$ arachidonoyl, $2 \mathrm{H}$ ), 1.54 (broad multiplet, $\mathrm{CH}-\mathrm{CH}_{2}-\mathrm{C}=\mathrm{O}$ stearoyl, $\left.2 \mathrm{H}\right), 1.2-1.4(\mathrm{~m}$, $\left.-\mathrm{CH}_{2}-, 32 \mathrm{H}\right), 0.85\left(\mathrm{~m},-\mathrm{CH}_{3}, 6 \mathrm{H}\right)$. Irradiation of the peak at $\delta 6.15$ caused the broad doublet at $\delta 7.9$ to collapse to a singlet, showing that the absorption at $\delta 7.4$ and $\delta 6.2$ are coupled and, therefore, due to the cytidine protons.

\section{Results}

\section{Synthetic CDPdiacylglycerols}

Commercially available 1,2-dipalmitoyl- or 1,2-distearoylPC was used as starting material for compounds I-IV (see legend, Fig. 1). To synthesize compounds V and VI, sn-glycero-3-phosphorylcholine was diacylated with arachidonic anhydride to give the diarachidonoylPC. The acylation reactions, carried out at room temperature, take $24-36 \mathrm{~h}$ for completion and proceed in 70 90\% yield. The NMR spectrum clearly shows the presence of stearoyl and arachidonoyl moieties in the 1-stearoyl-2-arachidonoylPC (Fig. 2; also see experimental section for NMR peak assignments). Alkaline methanolysis of PC and GLC analysis of the liberated fatty acid methyl esters provided fatty acid ratios (Table I). Examination of phospholipase $\mathrm{A}_{2}$-released fatty acids showed that 10 $15 \%$ acyl migration from the 1- to the 2-position had occurred (Table I). There was no evidence of further degradation of the lysoPC.

Silica gel chromatography did not separate CDPdiacylglycerols from unreacted CMPmorpholidate. The presence of the radioactive morpholidate raised the value of the enzyme blanks, which was particularly troublesome in the assay of relatively inactive substrates. This problem was overcome by the use of the DEAE-cellulose [25]. The purified 1-stearoyl-2-arachidonoyl CDPdiacylglycerol contained $96.5 \%$ of the theoretical amount of phosphorous based on a calculated molecular weight of 1063 for the anhydrous diammonium salt.

\section{Kinetic studies}

CDPdiacylglycerol:inositol phosphatidyltransferase. CDPdiacylglycerol : inositol phosphatidyltransferase activity against the synthetic substrates showed an absolute requirement for added detergent. The optimum concentration of Triton
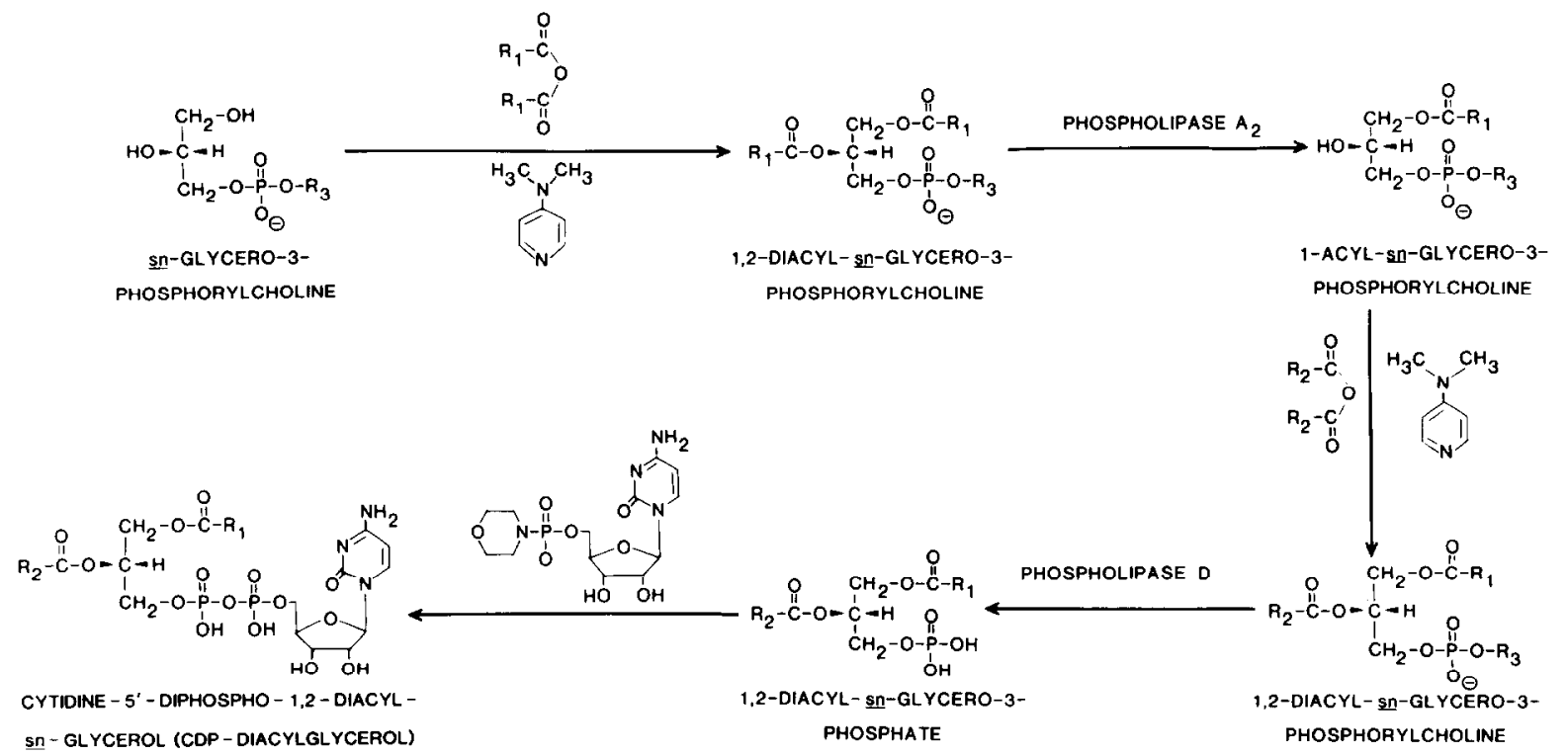

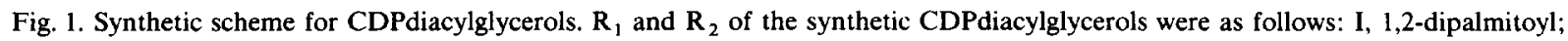
II, 1,2-distearoyl; III, 1,2-diarachidonoyl; IV, 1-stearoyl-2-arachidonoyl; V, 1-stearoyl-2-oleoyl; VI, 1-arachidonoyl-2-stearoyl. $\mathrm{R}_{3}=$ $-\mathrm{CH}_{2}-\mathrm{CH}_{2}-\mathrm{N}\left(\mathrm{CH}_{3}\right)_{3}^{+}$. 

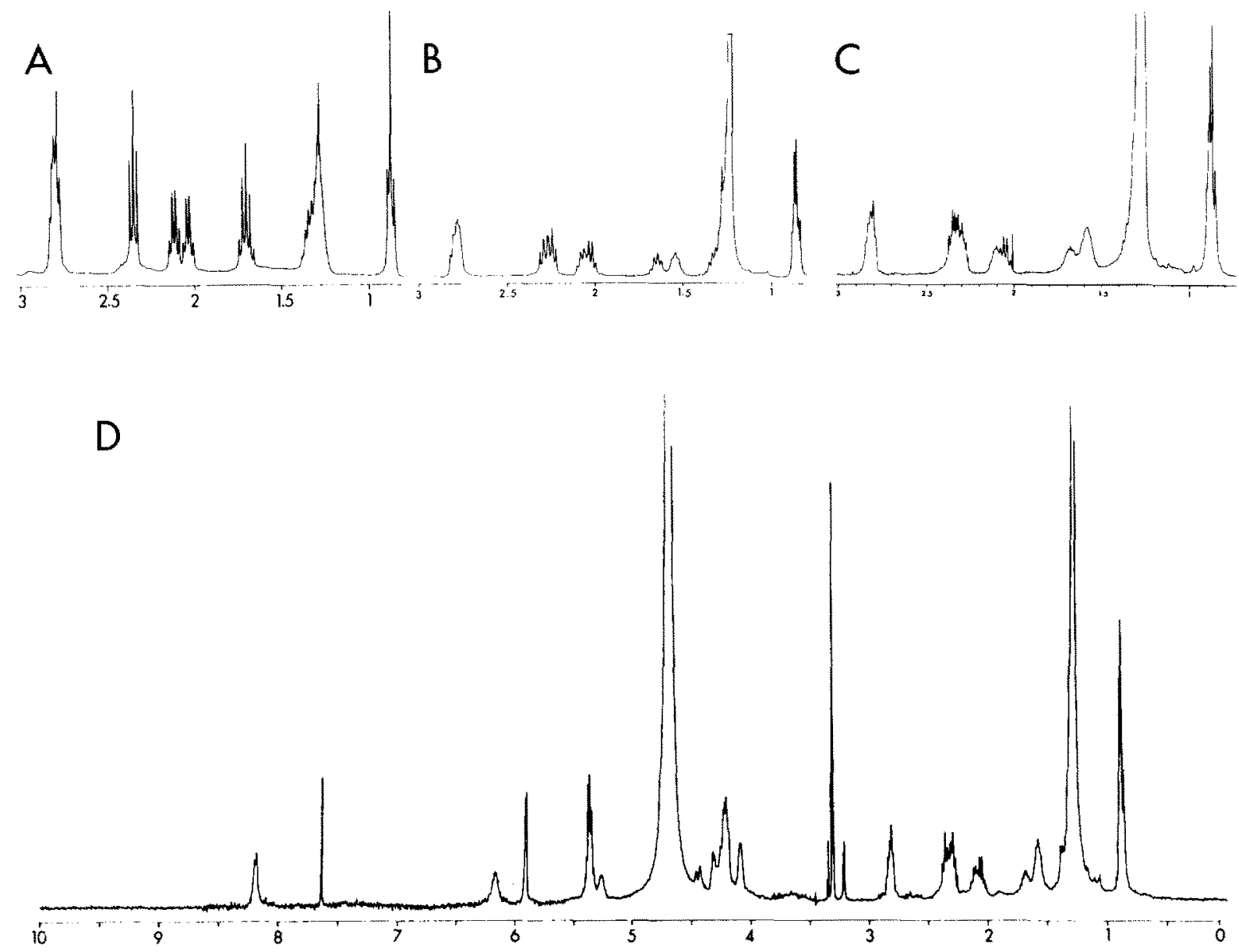

Fig. 2. $360 \mathrm{MHz}$ NMR spectra (80.8-3.0) of arachidonic acid, (A), 1-stearoyl-2-arachidonoylPC (B), and 1-stearoyl-2-arachidonoyl CDPdiacylglycerol (C). The complete spectrum of 1-stearoyl-2-arachidonoyl CDPdiacylglycerol is shown in D.

TABLE I

\section{FATTY ACID DISTRIBUTION IN SYNTHETIC LECITHINS}

For the alkaline methanolysis experiment, $\mathrm{PC}(100200 \mu \mathrm{g})$ was dissolved in $0.5 \mathrm{ml}$ of $\mathrm{CHCl}_{3} / \mathrm{CH}_{3} \mathrm{OH}(2: 3)$ and $0.5 \mathrm{ml}$ of $0.5 \mathrm{M}$ methanolic $\mathrm{NaOH}$ was added. After $30 \mathrm{~min}, 2 \mathrm{ml}$ of $\mathrm{CHCl}_{3} / \mathrm{CH}_{3} \mathrm{OH} / \mathrm{H}_{2} \mathrm{O}(2: 8: 10)$ was added. The lower layer was washed repeatedly with $\mathrm{CH}_{3} \mathrm{OH} / \mathrm{H}_{2} \mathrm{O}(10: 9)$ until neutral and concentrated. Fatty acid composition of the resultant methyl esters was analyzed by GLC. For the phospholipase $\mathrm{A}_{2}$ experiment, $500 \mu \mathrm{g}$ of $\mathrm{PC}$ was hydrolyzed with phospholipase $\mathrm{A}_{2}$ as described in Materials and Methods. The free fatty acids were esterified with methanolic $\mathrm{HCl}$ and analyzed by $\mathrm{GLC}$.

Mixed chain

phosphatidylcholine

preparation
Fatty acid liberated (\%)

By alkaline methanolysis

Arachidonic acid, 49

Stearic acid,

Olei acid,

Stearic acid,

Arachidonic acid,

Stearic acid,
49
51

45

55

48

52
By phospholipase $A_{2}$

Arachodonic acid, $\quad 85$

Stearic acid, $\quad 15$

Oleic acid, $\quad 87$

Stearic acid, $\quad 13$

Stearic acid, $\quad 87$

Arachidonic acid, $\quad 13$ 
TABLE II

KINETIC MEASUREMENTS OF CDP-DIACYLGLYCEROL : INOSITOL PHOSPHATIDYLTRANSFERASE WITH SYNTHETIC CDP-DIACYLGLYCEROL

All determinations were conducted in the presence of $0.15 \%$ Triton X-100 under standard assay conditions. $K_{\mathrm{m}}$ valucs are a result of least-squares analysis of $1 / v$ vs. $1 / S$ plots. Each value is the average of at least two determinations. Reaction rates were established with $40 \mu \mathrm{M}$ concentrations.

\begin{tabular}{lcc}
\hline CDPdiacylglycerol & $\begin{array}{l}K_{\mathrm{m}} \\
(\mu \mathrm{M})\end{array}$ & $\begin{array}{l}\text { Relative } \\
\text { reaction } \\
\text { rates }\end{array}$ \\
\hline 1-Stearoyl-2-oleoyl & 30 & 100 \\
Dipalmitoyl & 50 & 70 \\
Distearoyl & 160 & 37 \\
Diarachidonoyl & & 10 \\
1-Arachidonoyl-2-stearoyl & & 9 \\
1-Stearoyl-2-arachidonoyl & 45 & 4 \\
\hline
\end{tabular}

$\mathrm{X}-100$ was $0.15 \%$, at which level the enzyme follows Michaelis-Menten kinetics. Relative reaction rates at high substrate concentrations $[2,4]$ and $K_{m}$ of the various synthetic CDPdiacylglycerols with CDPdiacylglycerol : inositol phosphatidyltransferase are shown in Table II. 1-Stearoyl-2-oleoyl CDPdiacylglycerol showed the highest activity. All arachidonoyl-containing CDPdiacylglycerols were very poor substrates of CDPdiacylglycerol:inositol phosphatidyltransferase. The activity of 1stearoyl-2-arachidonoyl C.DPdiacylglycerol was only $4 \%$ of 1-stearoyl-2-oleoyl CDPdiacylglycerol activity and 1-arachidonoyl-2-stearoyl and diarachidonoyl CDPdiacylglycerols were only slightly more active than the 1-stearoyl-2arachidonoyl derivative.

To verify that the low activity of the arachidonoyl-containing lipids with CDPdiacylglycerol : inositol phosphatidyltransferase was not due to the inactivation of the enzyme by trace amounts of peroxides or other impurities from the arachidonoyl group, the enzyme preparation was preincubated with 1-stearoyl-2-arachidonoyl CDPdiacylglycerol before adding dipalmitoyl CDPdiacylglycerol. Results in Table III show that the 1-stearoyl-2-arachidonoyl CDPdiacylglycerol inhibited the conversion of dipalmitoyl CDPdiacylglycerol in a concentration-dependent manner. No peroxidation products were detected [26] in the 1-stearoyl-2-arachidonoyl CDPdiacylglycerol preparations. Addition of dithiothreitol did not protect the enzyme against Triton inactivation.

\section{CDPdiacylglycerol hydrolase}

As previously noted [15], CDPdiacylglycerol hy-

TABLE III

EFFECT OF PREINCUBATION WITH 1-STEAROYL-2-ARACHIDONOYL CDP-DIACYLGLYCEROL ON INOSITOL TRANSFERASE ACTIVITY

Mixtures containing $1.4 \mathrm{mM}$ inositol, $52.5 \mathrm{mM} \mathrm{MgCl}{ }_{2}, 175 \mathrm{mM}$ Tris-HCl buffer ( $\mathrm{pH} 8.3$ ) and $30 \mu \mathrm{g}$ of an enzyme preparation were preincubated as indicated at $37^{\circ} \mathrm{C}$ for $5 \mathrm{~min}$, except as noted below. The incubation mixtures were chilled and CDPdiacylglycerol (CDP-DAG) and Triton X-100 (20 $\mu 1$ of a 3\% solution) added to give $0.3 \%$ detergent concentration in a final volume of $0.2 \mathrm{ml}$. The mixtures were reincubated at $37^{\circ} \mathrm{C}$ for an additional $5 \mathrm{~min}$.

\begin{tabular}{|c|c|c|}
\hline Preincubation & Incubation & $\begin{array}{l}\text { CMP liberated } \\
(\mathrm{nmol})\end{array}$ \\
\hline 1. None & Dipalmitoyl CDP-DAG $(27 \mu \mathrm{M})+$ Triton & 1.4 \\
\hline 2. None & Dipalmitoyl CDP-DAG $(27 \mu \mathrm{M})^{\mathbf{a}}+$ Triton & 2.8 \\
\hline 3. $\mathrm{H}_{2} \mathrm{O}$ & Dipalmitoyl CDP-DAG $(27 \mu \mathrm{M})+$ Triton & 1.4 \\
\hline 4. Triton ${ }^{b}$ & Dipalmitoyl CDP-DAG $(27 \mu \mathrm{M})$ & 0 \\
\hline 5. None & 1-Stearoyl-2-arachidonoyl CDP-DAG $(52 \mu \mathrm{M})+$ Triton & 0.01 \\
\hline \multicolumn{3}{|c|}{ 6. 1-Stearoyl-2-arachidonoyl } \\
\hline CDP-DAG $(4.5 \mu \mathrm{M})$ & Dipalmitoyl CDP-DAG $(27 \mu \mathrm{M})+$ Iriton & 1.1 \\
\hline \multicolumn{3}{|c|}{ 7. 1-Stearoyl-2-arachidonoyl } \\
\hline CDP-DAG $(29 \mu \mathrm{M})$ & Dipalmitoyl CDP-DAG $(27 \mu \mathrm{M})+$ Triton & 0.8 \\
\hline
\end{tabular}

\footnotetext{
a Incubated for $10 \mathrm{~min}$.

b Triton was added prior to preincubation.
} 


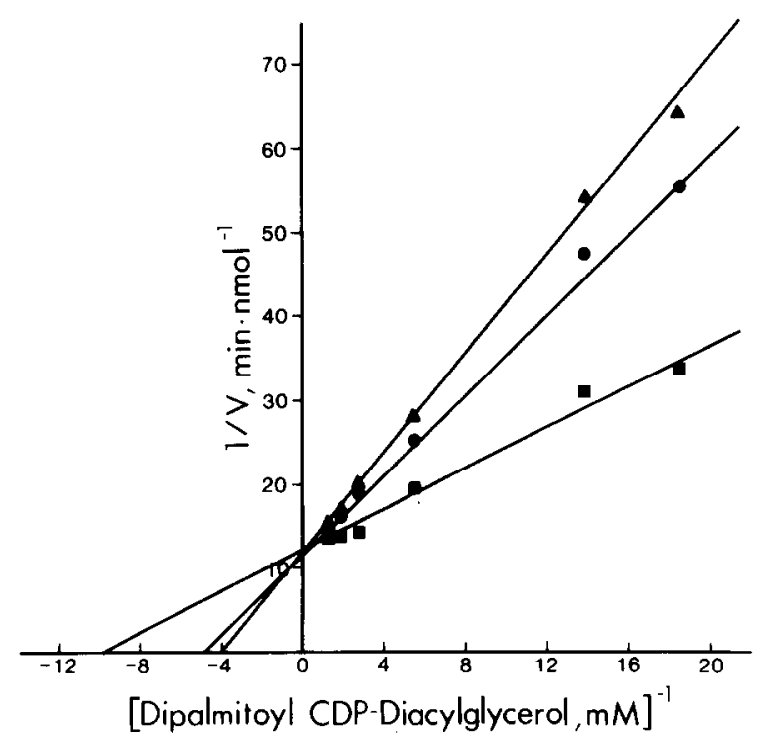

Fig. 3. Dependence of CDPdiacylglycerol hydrolase activity on dipalmitoyl CDPdiacylglycerol concentration at different Triton X-100 concentrations. $\square, 0.3 \% ; \ominus, 0.6 \% ; \mathbf{\Delta}, 0.9 \%$, Standard assay conditions were employed. Points represent averages of duplicate assays. Slopes are the result of least-squares analysis.

drolase activity was linear with time and protein concentration and had an absolute requirement for added detergent. The optimum concentration of Triton X-100 was $0.3 \%$. At constant detergent concentrations the enzyme followed Michaclis-

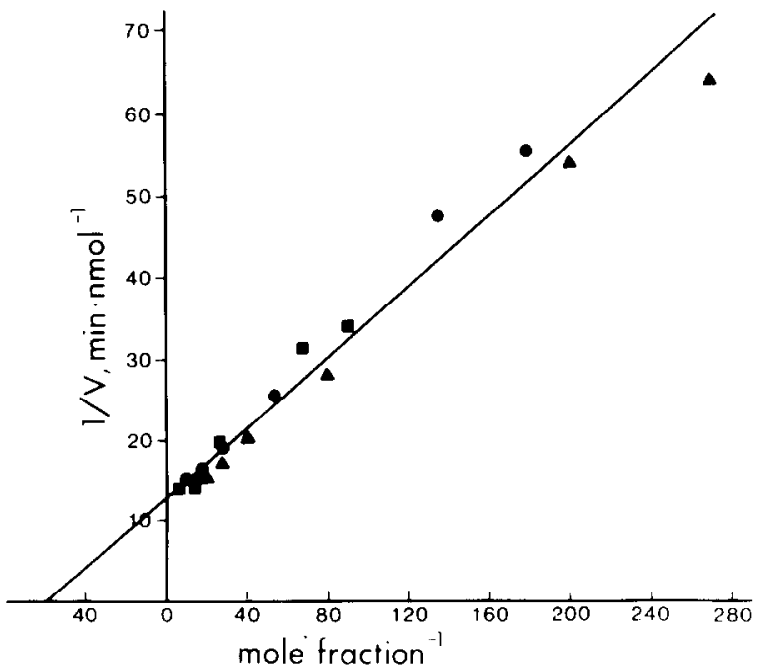

Fig. 4. Data in Fig. 2 recalculated to express concentration of dipalmitoyl CDPdiacylglycerol as mole fraction in mixed micelle with Triton X-100.
TABLE IV

KINETIC MEASUREMENTS OF CDP-DIACYLGLYCEROL HYDROLASE WITH SYNTHETIC CDP-DIACYLGLYCEROLS

All determinations were conducted in the presence of $0.3 \%$ Triton X-100 under standard assay conditions. $K_{\mathrm{m}}$ values were determined as in Table II. Reaction rates were established with $76 \mu \mathrm{M}$ substrate concentrations.

\begin{tabular}{lcc}
\hline CDPdiacylglycerols & $\begin{array}{l}K_{\mathrm{m}} \\
(\mu \mathrm{M})\end{array}$ & $\begin{array}{l}\text { Relative } \\
\text { reaction } \\
\text { rates }\end{array}$ \\
\hline 1-Stearoyl-2-oleoyl & 40 & 100 \\
Dipalmitoyl & 63 & 71 \\
Distearoyl & 140 & 39 \\
1-Stearoyl-2-arachidonoyl & 47 & 28 \\
1-Arachidonoyl-2-stearoyl & & 32 \\
Diarachidonoyl & & 22 \\
\hline
\end{tabular}

Menten kinetics (Fig. 3), although the apparent $K_{\mathrm{m}}$ increased as the concentration of Triton increased. This variation in $K_{\mathrm{m}}$ is not seen when the substrate concentration is expressed as the mole fraction of the substrate in the substrate-Triton X-100 micelle (Fig. 4).

The effect of varying the fatty acid substituents of CDPdiacylglycerol on the hydrolase is shown in

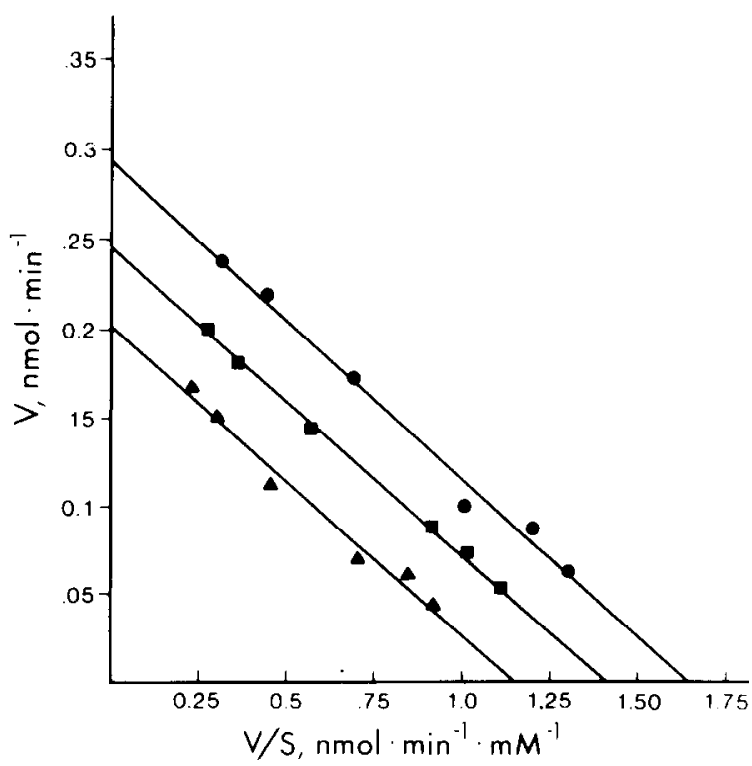

Fig. 5. Dependence of CDPdiacylglycerol hydrolase on dipalmitoyl CDPdiacylglycerol concentration in the presence of different concentrations of AMP. No AMP;, $0.01 \mathrm{mM}$ AMP; $\Delta, 0.03 \mathrm{mM}$ AMP. 
Table IV. The apparent $K_{\mathrm{m}}$ varied $30-40 \%$ with enzyme batches, possibly reflecting the differences in lipid content of the preparations. The value of $K_{\mathrm{n}}$ remained unchanged with the age of a given enzyme preparation as $V_{\max }$ decreased. 1-Stearoyl2-oleoyl CDPdiacylglycerol was the most active substrate. The presence of arachidonate in either the 1- or 2-position decreased the rate of hydrolysis.

The previously described inhibition of CDPdiacylglycerol hydrolase of bacterial or mammalian origin by AMP $[15,27]$ was studied. Kinetic analysis indicated that AMP lowered the $V_{\max }$ but did not affect the $K_{\mathrm{m}}$ (Fig. 5) of CDPdiacylglycerol hydrolase. The apparent $K_{\mathrm{i}}$ of AMP is 40 $\mu \mathrm{M}$.

\section{Subcellular localization of CDPdiacylglycerol hydro-} lase

Several lipid-metabolizing enzymes have been localized to peroxisomes [16]. Since peroxisomes of ten contaminate lysosomal fractions, it was possible that CDPdiacylglycerol hydrolase was a peroxisomal rather than a lysosomal enzyme. It was, therefore, of interest to separate peroxisomes from lysosomes. As shown in Fig. 6, the hydrolase accompanied the lysosomal and not the peroxisomal marker.

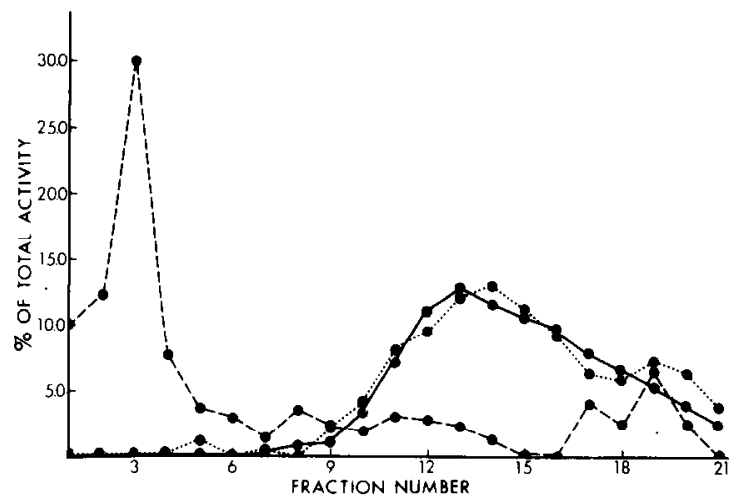

Fig. 6. Distribution pattern of CDPdiacylglycerol hydrolase (-) and marker enzymes (catalase, - - - ; acid phosphatase, (...) in guinea pig liver light mitochondrial fractions after centrifugation in a linear 20-60\% Metrizamide density gradient [16]. The fractions are numbered beginning at the bottom of the tube (60\% Metrizimide).

\section{Discussion}

Chemical synthesis of lecithins with different fatty acyl groups on the 1- and 2-sn-glycerol positions (hetero PCs) via 1 -acyl lysoPC retains steric purity, although positional problems arise due to acyl migration from the $1-$ to the 2-position of the lysoPC. To minimize acyl migration, it is desirable that the phospholipase $A_{2}$-catalyzed deacylation and the subsequent chemically catalyzed reacylation proceed rapidly and under mild conditions. $\mathrm{PC}$ rather than PA is used as the initial substrate, since the latter reacts only slowly and incompletely with the phospholipase $A_{2}$ preparation employed. The completeness of the deacylation of PC makes it unnecessary to purify the lysoPC intermediate, a step that would likely lead to further acyl migration. The subsequent dephosphorylation with phospholipase D is nearly quantitative. Introduction of fatty acid into lysoPC, rather than into lysoPA, also avoids the possibility of cyclization to the 2,3-phosphate ester. Investigation of the hetero PCs synthesized in the present study (Table I) by phospholipase $A_{2}$ action, followed by GLC, indicated that 85,82 and $85 \%$ of the 1-stearoyl-2arachidonoyl, 1-stearoyl-2-oleoyl and 1arachidonoyl-2-stearoyl preparations, respectively, were the desired regioisomer. This yield is somewhat less than was reported by Gupta et al. [21], who used dimethyl-4-aminopyridine as the catalyst. During the course of the present study, isomeric purity similar to ours with this catalyst were reported by Mason et al. [28], who additionally reported lysolecithin acylation in the presence of a different catalyst, 4-pyrrolidinopyridine.

CDPdiaglycerol hydrolase and CDPdiacylglycerol:inositol phosphatidyltransferase follow Michaelis-Menten kinetics at constant detergent concentration, unlike a number of lipolytic enzymes [29-32]. Apparent $V_{\max }$ of the reaction is independent of the concentration of Triton X-100, but $K_{\mathrm{m}}$ increases with the concentration of Triton (Fig. 3). The apparent inhibitory effect of high concentrations of Triton on enzyme activity is probably due to surface dilution, as suggested by Deems et al. [29]. That is, increasing the Triton concentration decreases the mole fraction of phospholipid in the phospholipid-Triton X-100 mixed micelle. 
While CDPdiacylglycerol is an obligatory intermediate for all bacterial phospholipids, and for only a fraction of mammalian phospholipids [33,34], CDPdiacylglycerol hydrolase from either source is inhibited by AMP. The high degree of specificity of the inhibitor [15] and its low $K_{\mathrm{i}}$ established in the present study suggest a regulatory role for the hydrolase. Localization of the hydrolase in purified liver lysosomal fraction is confirmed in the present study. While methods for obtaining purified brain lysosomes are not available, a similar distribution to that found in liver may be presumed to be found in nervous tissues.

Diacylglycerol and CDPdiacylglycerol isolated from various tissues, including brain, are highly enriched in the 1-stearoyl-2-arachidonoyl-snglycerol moiety [2,3]. Since each of these lipid classes is an intermediate in the biosynthesis of a variety of lipids, it is curious that the isolated substances reflect primarily a fatty acid characteristic of the phosphoinositides. Metabolic studies indicate that non-1-stearoyl-2-arachidonoylPI is formed initially $[35,36]$, is likely deacylated and the resultant lysoPI then reacylated with arachidonoyl-CoA. The present studies further preclude the likelihood that 1-stearoyl-2-arachidonoyl CDPdiacylglycerol is a precursor of 1-stearoyl-2arachidonoylPI, since it is a relatively poor substrate for the transferase reaction.

Isolated 1-stearoyl-2-arachidonoyl diacylglycerol may be the product of PI phospholipase C action on 1-stearoyl-2-arachidonoylPI [37]. 1-Stearoyl-2-arachidonoyl CDPdiacylglycerol could then be formed by phosphorylation of the diacylglycerol to 1-stearoyl-2-arachidonoylPA via diacylglycerol kinase, followed by conversion to CDPdiacylglycerol by the action of CTP:phosphatidate cytidylyltransferase [38,39]. It is alternatively possible that the isolated 1-stearoyl-2arachidonoyl CDPdiacylglycerol arises from 1stearoyl-2-arachidonoylPI and CMP via reversal of CDPdiacylglycerol:inositol phosphatidyltransferase [40]. The fatty acid specificity of phosphatidylinositols in the back-reaction is not known.

It is of interest that enzymatic deacylation of phosphatidylinositol, like the two enzymes described in the present study, is relatively inactive with the 1-stearoyl-2-arachidonoyl species [41]. The apparent relative resistance of arachidonate-con- taining lipids to this deacylase may in part account for the predominance of the 1-stearoyl-2-arachidonoyl moiety in isolated PI, while the relative inactivity of both the hydrolase and transferase for 1-stearoyl-2-arachidonoyl CDPdiacylglycerol could also account for the preponderance of the 1stearoyl-2-arachidonoyl moiety in isolated CDPdiacylglycerol. While arachidonate for prostanoid synthesis can come from a number of phospholipid classes [42], its release from 1-stearoyl-2arachidonoyl lipids may account for the wellknown phospholipid labeling effect and play a central regulatory role $[9,43]$.

\section{Acknowledgments}

The able assistance of Mr. Edward Seguin is gratefully acknowledged. We thank Mrs. Dorothy $\mathrm{Wu}$ for the lysosomal fractionation. This research was supported by NIH Grant NS 15413 .

\section{References}

1 Baker, R.R. and Thompson, W. (1972) Biochim. Biophys. Acta 270, 489-503

2 Thompson, W. and MacDonald, G. (1976) Eur. J. Biochem. $65,107-111$

3 Keough, K.M.W., MacDonald, G. and Thompson, W. (1972) Biochim. Biophys. Acta 270, 337-347

4 Thompson, W. and MacDonald, G. (1975) J. Biol. Chem. $250,6779-6785$

5 Bishop, H.H. and Strickland, K.P. (1970) Can. J. Biochem. 48, 269-277

6 Berridge, M.J. (1981) Mol. Cell. Endocrinol. 24, 115-140

7 Lapetina, E.G. and Cuatrecasas, P. (1979) Biochim. Biophys. Acta 573, 394-402

8 Rittenhouse-Simmons, S. and Deykin, D. (1981) in Platelets in Biology and Pathology (Gordon, J.I., ed.), pp. 349-372, Elsevier/North Holland Publishing Company, New York

9 Agranoff, B.W. and Fisher, S.K. (1982) in Phospholipid Metabolism in the Nervous System (Horrocks, L., Ansell, G.B. and Porcellati, G., eds.), Raven Press, New York, in the press

10 Dittmer, J.C. and Lester, R.L. (1964) J. Lipid Res. 5, 126-127

11 Fewster, F.E., Burns, B.J. and Mead, J.F. (1969) J. Chromatogr. 43, 120-126

12 Geiger, P.J. and Bessman, S.P. (1972) Anal. Biochem. 49, $467-473$

13 Ames, B.N. and Dubin, D.T. (1960) J. Biol. Chem. 235, $769-775$

14 Benjamins, J.A. and Agranoff, B.W. (1969) J. Neurochem. $16,513-527$

15 Rittenhouse, H.G., Seguin, E.B., Fisher, S.K. and Agranoff, B.W. (1981) J. Neurochem. 36, 991-999 
16 Hajra, A.K. and Bishop, J.E. (1982) Ann. New York Acad. Sci. $386,170-182$

17 Peters, T.J., Muller, M. and De Duve, C. (1972) J. Exp. Med. 136, 1117-1139

18 Baudhuin, P. (1974) Methods Enzymol. 31, 356-368

19 Selinger, Z. and Lapidot, Y. (1966) J. Lipid Res. 7, 174-175

20 Chakrabarti, P. and Khorana, H.G. (1975) Biochemistry 14, 5021-5033

21 Gupta, C.M., Radhakrishnan, R. and Khorana, H.G. (1977) Proc. Natl. Acad. Sci. U.S.A. 74, 4315-4319

22 Kates, M. (1972) Techniques of Lipidology, pp. 479-480, North-Holland Publishing Company, Amsterdam

23 Razzell, W.E. (1963) Methods Enzymol. 6, 236-238

24 Agranoff, B.W. and Suomi, W.D. (1963) in Biochemical Preparations (Brown, G.B., ed.), Vol. 10, pp. 47-51, Wiley and Sons, New York

25 MacCoss, M., Ryu, E.K. and Matsushita, T. (1978) Biochem. Biophys. Res. Comm. 85, 714-723

26 Kokatnur, M.G., Bergan, J.G. and Draper, H.H. (1965) Anal. Biochem. 12, 325-331

27 Raetz, C.R.H., Dowhan, W. and Kennedy, E.P. (1976) J. Bacteriol. 125, 855-863

28 Mason, J.T., Broccoli, A.V. and Huang, C.-H. (1981) Anal. Biochem. 113, 96-101

29 Deems, R.A., Eaton, B.R. and Dennis, E.A. (1975) J. Biol. Chem. 250, 9013-9020

30 Eaton, B.R. and Dennis, E.A. (1976) Arch. Biochem. Biophys. 176, 604-609
31 Warner, T.G. and Dennis, E.A. (1975) J. Biol. Chem. 250, 8004-8009

32 Carman, G.M. and Dowhan, W. (1979) J. Biol. Chem. 254, 8391-8397

33 Lennarz, W.J. (1970) in Lipid Metabolism (Wakil, S.J., ed.) pp. 155-184, Academic Press, New York

34 Hill, E.E. and Lands, W.E.M. (1970) in Lipid Metabolism (Wakil, S.J., ed.), pp. 185-277, Academic Press, New York

35 Holub, B.J. (1975) Lipids 11, 1-5

36 Holub, B.J. and Kuksis, A. (1971) J. Lipid Res. 12, 699-705

37 Irvine, R.F., Hemington, N. and Dawson, R.M.C. (1979) Eur. J. Biochem. 99, 525-530

38 Bishop, H.H. and Strickland, K.P. (1980) Lipids 15, 285-291

39 Bishop, H.H. and Strickland, K.P. (1976) Can. J. Biochem. $54,249-260$

40 Petzold, G.L. and Agranoff, B.W. (1967) J. Biol. Chem. 242, 1187-1191

41 Strickland, K.P. and Gray, N.C.C. (1981) Abstract, International Society for Neurochemistry Satellite Meeting Phospholipid Metabolism in the Nervous System, Birmingham, U.K. p. 78

42 Broekman, M.J., Ward, J.W. and Marcus, A.J. (1981) J. Biol. Chem. 256, 8271-8274

43 Agranoff, B.W. and Bleasdale, J.E. (1978) in Cyclitols and Phosphoinositides (Eisenberg, F., Jr. and Wells, W.W., eds.), pp. 105-120, Academic Press, New York 